\title{
EFEKTIVITAS DISTRIBUSI RASKIN DI PEDESAAN DAN PERKOTAAN INDONESIA
}

\author{
Jamhari \\ Jurusan Sosial Ekonomi Pertanian Fakultas Pertanian Universitas Gadjah Mada \\ Jalan Flora Bulaksumur Yogyakarta 55281 Telepon/Faks. 0274-516656 \\ E-mail: jamhari@ugm.ac.id
}

Diterima 4 April 2011 / Disetujui 15 Mei 2012

\begin{abstract}
This research aims to investigate effectiveness of rice for the poor program (Raskin) in rural and urban Indonesia based on the National Socio Economic Survey data (Susenas) collected by Central Bureau of Statistic (BPS) in 2007. Number of sample was 52,370 households. Effectiveness of Raskin Program was measured by target, quantity and price accuracy indexes. Logistic regression model was used to identify factors affecting probability of a household to receive raskin or not. The results of analysis show that raskin distribution was not yet accurately reach the target beneficiaries. Raskin distribution was also not accurate in quantity and price. Quantity accuracy index was 58 percent in rural, 53 percent in urban and 57 percent in Indonesia. Price quantity index was 68 percent in rural, 63 percent in urban and 67 percent in Indonesia. Probability of a household to receive raskin was affected by education, gender, age, household member, income, employment, floor condition and location.
\end{abstract}

Keywords: raskin distribution, accuracy index, poor households, rural

\begin{abstract}
Abstrak: Penelitian ini bertujuan untuk mengkaji efektivitas distribusi raskin di pedesaan dan perkotaan Indonesia serta mengidentifikasi faktor penentu suatu rumah tangga menerima raskin atau tidak dengan menggunakan data Susenas tahun 2007. Sampel yang digunakan sebanyak 52.370 rumah tangga. Efektivitas distribusi raskin diukur dengan indikator ketepatan sasaran, jumlah dan harga. Sedangkan model regresi logistik (logit) digunakan untuk mengetahui faktor-faktor yang menentukan suatu rumah tangga menerima raskin atau tidak. Hasil penelitian menunjukkan bahwa distribusi raskin di Indonesia belum tepat sasaran. Distribusi raskin di Indonesia belum tepat jumlah dan harga. Indeks ketepatan jumlah 58 persen di pedesaan, 53 persen di perkotaan dan 57 persen secara nasional. Indeks ketepatan harga 68 persen di pedesaan, 63 persen di perkotaan dan 67 persen secara nasional. Probabilitas suatu rumah tangga menerima raskin atau tidak dipengaruhi oleh pendidikan, jenis kelamin, umur, jumlah anggota rumah tangga, pendapatan, pekerjaan, lantai rumah dan lokasi.
\end{abstract}

Kata kunci: distribusi raskin, indeks ketepatan, rumah tangga miskin, pedesaan

\section{PENDAHULUAN}

Kemiskinan menjadi tantangan utama pembangunan saat ini, bahkan dunia internasional telah menetapkan penanggulangan kemiskinan sebagai Millenium Development Goals (MDGs). Secara teoritis dan empiris telah dipahami bahwa usaha penanggulangan kemiskinan tidak dapat diserahkan sepenuhnya pada mekanisme pasar (market mechanism) karena pasar hanya bekerja atas dasar efisiensi alokasi sumberdaya. Terjadinya kegagalan pasar (market failure) akan menyebabkan tujuan pembangunan untuk mengentaskan kemiskinan tidak efektif. Oleh karena itu intervensi pemerintah dalam bentuk kebijakan publik diperlukan untuk mengoreksi kegagalan pasar dan meningkatkan efektivitas pembangunan dalam mewujudkan kesejahtera- 
an masyarakat (Dunn, 2000; Gruber, 2005; Stiglitz, 2000).

Raskin merupakan salah satu bentuk kebijakan publik pemerintah Indonesia dalam mendistribusikan beras khusus untuk rumah tangga miskin (Tabor and Sawit, 2001). Program Raskin dimulai sejak tahun 1998 dengan nama OPK (Operasi Pasar Khusus) yang berfungsi sebagai program darurat (social safety net) untuk memperkuat ketahanan pangan rumah tangga miskin setelah krisis moneter terjadi tahun 1997. Pada tahun 2002, fungsi program diperluas sebagai perlindungan sosial masyarakat (social protection) dan namanya diubah menjadi Raskin agar lebih tepat sasaran (Bulog, 2010a).

Data dasar penerima manfaat raskin mengalami beberapa kali perubahan. Sampai dengan tahun 2006, data BKKBN yang terdiri atas keluarga prasejahtera alasan ekonomi dan keluarga sejahtera I alasan ekonomi digunakan sebagai data dasar penerima manfaat Raskin. Namun demikian kriteria penerima manfaat Raskin selalu menjadi persoalan sehingga musyawarah Desa/Kelurahan (Mudes) dijadikan sebagai pertimbangan dalam menentukan rumah tangga sasaran. Sejak tahun 2007, data Rumah Tangga Miskin (RTM) Biro Pusat Statistik (BPS) digunakan sebagai data dasar penerima manfaat raskin. Secara operasional, Menteri Koordinator Kesejahteraan Rakyat (Menko Kesra) menjadi koordinator pelaksanaan Program Raskin, Bulog bertanggung jawab mendistribusikan beras sampai titik distribusi, dan pemerintah daerah bertanggungjawab menyalurkan beras dari titik distribusi kepada RTM.

Jumlah dan harga raskin yang diberikan kepada rumah tangga miskin juga telah mengalami perubahan. Sampai dengan tahun 2007, pagu raskin yang diberikan sebesar $20 \mathrm{~kg} / \mathrm{KK} /$ bulan dengan harga Rp1.000/kg di titik distribusi. Mulai tahun 2008, pagu raskin diturunkan menjadi $15 \mathrm{~kg} / \mathrm{KK} /$ bulan dengan harga Rp1.600 /KK/bulan (Departemen Dalam Negeri dan Perum Bulog, 2007 dan 2008).

Permasalahan utama Program Raskin adalah kurang tepatnya sasaran penerima manfaat karena kesalahan persepsi masyarakat dan aparat desa mengenai Program Raskin. Banyak kasus di lapangan menunjukkan bahwa raskin dibagi rata atau bergilir karena alasan sosial, kebersamaan, gotong royong dan sebagainya. Masih terdapat masyarakat yang tidak termasuk dalam kategori miskin, tetapi minta jatah raskin. Sebaliknya masih ada rumah tangga miskin yang belum menerima raskin (Bulog, 2010b; Hastuti dkk., 2008; Adinugroho, 2010; Sidik, 2009; Prasmatiwi, 2010; Purwanti, 2010; serta Asmara dan Hutagaol, 2009).

Berdasarkan latar belakang tersebut penelitian ini bertujuan untuk mengkaji lebih lanjut efektivitas distribusi raskin di Indonesia dari aspek ketepatan sasaran, jumlah dan harga serta mengidentifikasi faktor-faktor yang menentukan suatu rumah tangga menerima raskin atau tidak. Hasil penelitian ini bermanfaat untuk merumuskan kembali Program Raskin yang lebih efektif dan pro-poor.

Menurut Pedoman Umum (Pedum) Raskin keberhasilan Program Raskin diukur dengan indikator 6T (tepat sasaran, tepat jumlah, tepat harga, tepat waktu, tepat kualitas, dan tepat administrasi). Program Raskin tepat sasaran apabila raskin hanya diberikan pada keluarga miskin yang terdaftar dalam Daftar Penerima Manfaat (DPM-I), tepat jumlah apabila jumlah raskin yang dibeli oleh keluarga sasaran penerima manfaat sama dengan pagu jumlah raskin sebesar $20 \mathrm{~kg} / \mathrm{KK} /$ bulan, dan tepat harga apabila harga yang dibayarkan oleh penerima manfaat sebesar Rp1.000/kg di titik distribusi.

Bulog (2010b) melaporkan beberapa hasil studi evaluasi pelaksanaan raskin baik pada era Program OPK maupun Program Raskin. Pada tahun 1999 studi evaluasi pelaksanaan OPK antara lain dilakukan oleh LP3ES (Lembaga Penelitian, Pendidikan dan Penerangan Ekonomi dan Sosial), CEFFNAS (Centre for Food, Nutrition and Agriculture Studies and Services), UGM (Universitas Gadjah Mada), Harvard Institute For International Development-USA, dan EMSI (Economic Management Services International). LP3ES menemukan adanya ketidaksesuaian antara kriteria dengan realitas penerima OPK beras sehingga perlu penajaman sasaran, pelibatan LSM/Lembaga Swadaya Masyarakat dalam pendistribusian serta perlunya peningkatan sosialisasi. CEFFNAS menyarankan agar distribusi OPK disesuaikan dengan pola panen padi, 
perlunya pola bottom-up dalam penentuan kelompok sasaran serta peningkatan sosialisasi untuk penetapan prioritas target sasaran. Sedangkan tim peneliti UGM merekomendasikan pendataan ulang keluarga sasaran dengan metode yang lebih realistis dan rasional, penggantian nama OPK untuk mempertajam makna program, peningkatan sosialisasi, pemakaian kemasan paket $20 \mathrm{~kg}$ dan pengawasan yang lebih baik.

Studi evaluasi pelaksanaan OPK oleh Harvard Institute for International Development-USA menyimpulkan bahwa program pendistribusian beras untuk masyarakat miskin secara langsung pada kelompok sasaran merupakan upaya yang terbaik dalam mengatasi masalah rawan pangan. Sedangkan penelitian EMSI menunjukkan bahwa OPK telah meningkatkan pendapatan nasional sebesar 6,4 triliun pada tahun pertama, meningkatkan pendapatan 72.000 pencari kerja baru dengan biaya penciptaan kerja sebesar Rp476.000. Di samping itu OPK dapat dipandang sebagai transfer pendapatan pemerintah secara tidak langsung terhadap keluarga miskin dengan rasio transfer keuntungan bersih terhadap biaya total sebesar 85 persen, rasio keuntungan bersih penerima OPK terhadap biaya finansial 106 persen, dan rasio biaya operasional terhadap transfer keuntungan bersih 10 persen. Apabila program OPK tidak ada maka pendapatan masyarakat miskin akan turun 11 persen, dan pendapatan masyarakat paling miskin akan menurun lebih besar lagi yaitu 22 persen. Tanpa program OPK, konsumsi kalori keluarga miskin berkurang 8 persen dan konsumsi protein turun 15 persen.

Pada tahun 2004 studi evaluasi pelaksanaan Program Raskin antara lain dilaksanakan oleh Universitas Brawijaya dan Lembaga Demografi Universitas Indonesia. Hasil penelitian kedua lembaga tersebut masih menemukan pembagian raskin yang kurang tepat, jumlah beras yang dibagikan kurang dari $20 \mathrm{~kg} / \mathrm{KK} /$ bulan dan hampir semua daerah melakukan modifikasi berdasarkan musyawarah desa yang ditegaskan dengan SK Gubernur/Bupati/Walikota. Tim Peneliti Universitas Brawijaya menyarankan perlunya Sistem Informasi Pangan Nasional (SIPN) dan penguatan kelembagaan lokal untuk mengantisipasi kerawanan pangan.

Tim Peneliti Lembaga Demografi UI menemukan bahwa kuantitas beras yang dibeli oleh KK penerima manfaat bervariasi antara 3,5 - 20 $\mathrm{kg} / \mathrm{KK}$ karena jumlah KK miskin yang membutuhkan lebih banyak daripada jumlah beras yang didistribusikan, tidak mempunyai cukup uang untuk membeli beras sebanyak $20 \mathrm{~kg}$, titik distribusi raskin sulit dijangkau dan kualitas beras yang kurang baik. Tim Peneliti Lembaga Demografi UI mengestimasi nilai ketepatan sasaran distribusi raskin sebesar 86 persen. Oleh karena itu tim menyarankan agar dibentuk institusi khusus di level bawah (tingkat penerima manfaat) misalnya Kelompok Kerja Penanggulangan Kemiskinan Tingkat Desa/Kelurahan beranggotakan tokoh masyarakat setempat.

Hastuti dkk. (2008) menemukan bahwa secara umum efektivitas pelaksanaan Raskin masih relatif lemah, permasalahan banyak terjadi dari titik distribusi hingga rumah tangga penerima, dan jenis permasalahannya relatif sama dari tahun ke tahun. Rendahnya efektivitas program ditandai oleh kurangnya sosialisasi dan transparansi program; tidak tepatnya sasaran penerima, harga, jumlah, dan frekuensi penerimaan beras; tingginya biaya pengelolaan program; belum optimalnya pelaksanaan monitoring dan evaluasi; dan kurang berfungsinya mekanisme pengaduan.

Hutagaol dan Asmara (2008) menyimpulkan bahwa distribusi raskin di provinsi Jawa Barat belum efektif karena tidak tepat jumlah dan harga. Penelitian di provinsi Jawa Tengah oleh Purwanti (2010) juga menyimpulkan bahwa distribusi Raskin di kecamatan Salam kabupaten Magelang belum tepat sasaran, jumlah dan harga. Jumlah raskin yang diterima rumah tangga $6,45 \mathrm{~kg}$ dengan harga $1.699 / \mathrm{kg}$. Jumlah RTS (rumah tangga sasaran) yang tergolong tidak miskin sebesar 43,33 persen dan rumah tangga miskin yang tidak terdaftar sebagai rumah tangga penerima raskin juga sebesar 43,33 persen.

Evaluasi Program Raskin di provinsi DIY juga menghasilkan kesimpulan yang sama. Siddik (2009) menemukan bahwa program Raskin di kecamatan Depok kabupaten Sleman 
belum tepat sasaran, jumlah dan harga; tetapi sudah tepat frekuensi. Jumlah beras yang diterima rumah tangga sebesar $13 \mathrm{~kg}$ dari seharusnya $15 \mathrm{~kg}$ dengan harga Rp1.760/kg dari seharusnya Rp1.600/kg. Lebih lanjut Prasmatiwi (2010) menyimpulkan bahwa distribusi raskin di Kabupaten Sleman belum tepat sasaran, jumlah, harga, kualitas dan frekuensi. Jumlah raskin yang diterima $8,8 \mathrm{~kg}$ dengan harga $\mathrm{Rp} 1.750 / \mathrm{kg}$. Distribusi raskin di kabupaten Sleman baru tepat administrasi.

Adinugroho (2010) lebih khusus mengevaluasi distribusi raskin Perum Bulog Divre Kalimantan Timur di Kota Balikpapan sampai dengan titik distribusi menyimpulkan bahwa distribusi raskin sampai titik distribusi sudah efektif (tepat sasaran, jumlah, harga, waktu, administrasi dan kualitas) dan sangat efisien.

Dari hasil-hasil penelitian di atas dapat disimpulkan sementara bahwa raskin bermanfaat bagi rumah tangga penerima, namun belum tepat sasaran, jumlah dan harga. Penelitian ini akan menguji kesimpulan sementara tersebut untuk skala yang lebih luas yaitu Indonesia, membandingkan efektivitas distribusi raskin di pedesaan dan perkotaan serta mengidentifikasi lebih lanjut faktor-faktor yang menentukan suatu rumah tangga menerima raskin atau tidak.

\section{METODE PENELITIAN}

Data yang digunakan dalam penelitian ini merupakan data sekunder hasil Susenas (Survei Sosial Ekonomi Nasional) BPS tahun 2007. Jumlah sampel penelitian sebanyak 52.370 rumah tangga terdiri atas 31.675 (60,48 persen) rumah tangga pedesaan dan 20.695 (39,52 persen) rumah tangga perkotaan. Rumah tangga sampel tersebut berasal dari seluruh provinsi yang ada di Indonesia. Untuk menguji hipotesis tentang ketepatan sasaran, jumlah dan harga raskin maka dilakukan teknik analisis data sebagai berikut:

(1) Pengelompokan rumah tangga. Rumah tangga sampel dikelompokkan menjadi rumah tangga miskin dan tidak miskin berdasarkan garis kemiskinan BPS (2007). Rumah tangga pedesaan termasuk miskin apabila pengeluarannya kurang dari Rp146.837/kapita/bulan dan sebaliknya; sedangkan rumah tangga perkotaan termasuk miskin apabila pengeluarannya kurang dari Rp187.942/kapita/bulan dan sebaliknya. Perbedaan antara rata-rata pengeluaran kelompok rumah tangga dan garis kemiskinan diuji dengan Uji t sebagai berikut:

thitung $=\frac{Y_{1}-Y_{0}}{s_{Y 1} / \sqrt{n}}$

di mana: $Y_{1}$ adalah rata-rata pengeluaran kelompok rumah tangga, $\mathrm{Y}_{0}$ adalah garis kemiskinan BPS (2007), SY1 adalah standar deviasi pengeluaran kelompok rumah tangga, $\mathrm{n}$ adalah jumlah rumah tangga sampel.

2) Ketepatan sasaran. Untuk mengetahui tingkat ketepatan sasaran maka dibuat tabulasi silang (cross tabulation) antara data kelompok rumah tangga dengan data rumah tangga penerima raskin serta dihitung indeks ketepatan sasaran sebagai berikut:

$I K S=100 \%-\frac{R_{1}}{R_{0}}-\frac{R_{2}}{R_{0}}$

di mana IKS adalah indeks ketepatan sasaran, $\mathrm{R}_{0}$ adalah jumlah rumah tangga miskin, $\mathrm{R}_{1}=$ jumlah rumah tangga miskin yang tidak menerima raskin, $R_{2}$ adalah jumlah rumah tangga tidak miskin yang menerima raskin, IKS kurang dari 100 (IKS $\leq 100$ ), semakin besar IKS maka distribusi raskin semakin tepat sasaran.

(3) Ketepatan jumlah. Untuk mengetahui tingkat ketepatan jumlah dalam distribusi raskin di Indonesia maka dihitung indeks ketepatan jumlah dan uji t sebagai berikut:

\section{(a) Indeks ketepatan jumlah}

$$
I K J=\frac{Q_{1}}{Q_{0}} \times 100 \%
$$

di mana IKJ adalah indeks ketepatan jumlah, $\mathbf{Q}_{0}$ adalah jumlah raskin program sebesar 20 $\mathrm{kg} / \mathrm{KK} /$ bulan, $\mathbf{Q}_{1}$ adalah jumlah raskin aktual yang diterima rumah tangga $(\mathrm{kg} / \mathrm{KK} /$ bulan$)$. IKJ terletak antara 0 dan $100(0 \leq \mathrm{IKJ} \leq 100)$, semakin besar IKJ maka distribusi raskin semakin tepat jumlah. 
b) Uji $t$ ketepatan jumlah. Uji $\mathrm{t}$ ketepatan jumlah dilakukan untuk mengetahui perbedaan antara rata-rata jumlah raskin yang diterima rumah tangga dengan pagu jumlah raskin sebesar $20 \mathrm{~kg} / \mathrm{KK} /$ bulan

$$
\text { thitung }=\frac{Q_{1}-Q_{0}}{s_{Q 1} / \sqrt{n}}
$$

di mana $\mathbf{S}_{\mathbf{Q} 1}$ adalah standar deviasi jumlah raskin yang diterima rumah tangga, $\mathbf{n}$ adalah jumlah rumah tangga sampel

(4) Ketepatan Harga. Untuk mengetahui tingkat ketepatan harga raskin di Indonesia maka dihitung indeks ketepatan harga dan uji $t$ sebagai berikut:

\section{(a) Indeks ketepatan harga}

$$
I K H=100 \%-\frac{\left(P_{1}-P_{0}\right)}{P_{0}} \times 100 \%
$$

di mana IKH adalah indeks ketepatan harga, $\mathbf{P}_{\mathbf{0}}$ adalah harga raskin program sebesar Rp1.000/ $\mathrm{kg})$. $\mathbf{P}_{\mathbf{1}}$ adalah harga raskin aktual yang dibayarkan oleh rumah tangga $(\mathrm{Rp} / \mathrm{kg})$.

IKH kurang dari 100 (IKH $\leq 100)$, semakin besar IKH maka distribusi raskin semakin tepat harga.

(b) Uji t ketepatan harga. Uji t ketepatan harga dilakukan untuk mengetahui perbedaan antara rata-rata harga raskin yang dibayarkan oleh rumah tangga dengan pagu harga raskin sebesar $\mathrm{Rp} 1.000 / \mathrm{kg}$

thitung $=\frac{P_{1}-P_{0}}{s_{P 1} / \sqrt{n}}$

di mana $\mathbf{S}_{\mathbf{P 1}}$ adalah standar deviasi harga raskin aktual yang dibayarkan oleh rumah tangga. $\mathbf{n}$ adalah jumlah rumah tangga sampel.

Cara perhitungan indeks yang digunakan dalam penelitian ini merupakan modifikasi dari cara perhitungan yang ada dalam dalam Pedum Raskin. Modifikasi dilakukan karena teknik analisis dalam Pedum Raskin menghasilkan nilai IKS, IKJ dan IKH yang tidak konsisten (IKS dan IKH lebih besar dari atau sama dengan 100, sebaliknya IKJ kurang dari atau sama dengan 100). Teknik analisis dalam penelitian ini menghasilkan nilai indeks yang konsisten (IKS, IKJ dan IKH kurang dari atau sama dengan 100). Kondisi ideal distribusi raskin yaitu tepat sasaran, jumlah dan harga tercapai apabila masing-masing indeksnya bernilai 100; dan tidak tepat sasaran, jumlah dan harga apabila nilai indeksnya kurang dari 100. Semakin besar IKS, IKJ, dan IKH maka distribusi raskin semakin tepat sasaran, jumlah dan harga.

5) Faktor-faktor yang mempengaruhi rumah tangga menerima raskin. Untuk mengetahui faktor-faktor yang menentukan suatu rumah tangga menerima raskin atau tidak digunakan model regresi logistik sebagai berikut:

$$
L_{i}=\ln \left(\frac{P_{i}}{1-P_{i}}\right)=\beta_{0}+\beta_{1} X_{1}+\beta_{2} X_{2}+\ldots+\beta_{8} X_{8}
$$

di mana $\mathbf{L}_{\mathbf{1}}$ adalah penerimaan raskin (1-menerima raskin, 0-lainnya), $\mathbf{X}_{\mathbf{1}}$ adalah pendidikan kepala rumah tangga (1-tidak tamat SD, 2-SD, 3-SLTP, 4-SLTA, 5-Diploma, 6-S1 dan 7-Pascasarjana), $\mathbf{X}_{\mathbf{2}}$ adalah jenis kelamin kepala rumah tangga (1-laki-laki, 0-perempuan), $\mathbf{X}_{3}$ adalah umur kepala rumah tangga (tahun), $\mathbf{X}_{\mathbf{4}}$ adalah jumlah anggota rumah tangga (orang), $\mathbf{X}_{5}$ adalah pendapatan per kapita rumah tangga ( $\mathrm{Rp} /$ kapita/bulan), $\mathbf{X}_{6}$ adalah pekerjaan (1-pertanian, 0-lainnya), $\mathbf{X}_{7}$ adalah lantai rumah (1-bukan tanah, 0 -tanah), $\mathbf{X}_{8}$ adalah lokasi (1-kota, 0-desa), $\boldsymbol{\beta}_{0}$ adalah konstanta, $\boldsymbol{\beta}_{1} \ldots \boldsymbol{\beta}_{8}$ adalah koefisien regresi

\section{HASIL DAN PEMBAHASAN}

\section{Rumah Tangga Miskin dan Rumah Tangga Penerima Raskin}

Berdasarkan garis kemiskinan BPS (2007), rumah tangga sampel dapat dikelompokkan menjadi rumah tangga miskin (RTM) sebesar 7.869 (15,03 persen) dan rumah tangga tidak miskin 44.501 (84,97 persen). Jumlah RTM di pedesaan $5.770(18,22$ persen dari rumah tangga pedesaan), sedangkan RTM di perkotaan sebanyak 2.099 (10,14 persen dari rumah tangga perkotaan). Secara lebih rinci jumlah dan persentase RTM dapat dilihat pada Tabel 1. 
Tabel 1. Jumlah dan Persentase Rumah Tangga Miskin dan Tidak Miskin Berdasarkan Garis Kemiskinan BPS (2007)

\begin{tabular}{lcccccc}
\hline \multicolumn{1}{c}{ Lokasi } & \multirow{2}{*}{ RTM } & \multicolumn{2}{c}{ Non RTM } & \multicolumn{2}{c}{ Jumlah } \\
& RT & $\mathbf{0}$ & RT & \% & RT & \% \\
\hline Desa & 5.770 & $18,22 \%$ & 25.905 & $81,78 \%$ & 31.675 & $100,00 \%$ \\
Kota & 2.099 & $10,14 \%$ & 18.596 & $89,86 \%$ & 20.695 & $100,00 \%$ \\
Indonesia & 7.869 & $15,03 \%$ & 44.501 & $84,97 \%$ & 52.370 & $100,00 \%$ \\
\hline
\end{tabular}

Sumber: Analisis Data Susenas (2007)

Keterangan: RT adalah rumah tangga, RTM adalah rumah tangga miskin, Non RTM adalah rumah tangga tidak miskin

Rata-rata pengeluaran RTM baik di pedesaan, perkotaan maupun nasional secara signifikan $(a=1 \%)$ berada di bawah garis kemiskinan, sedangkan rata-rata pengeluaran rumah tangga tidak miskin baik di pedesaan, perkotaan maupun nasional berada di atas garis kemiskinan. Rata-rata pengeluaran RTM di pedesaan Rp119.420/kapita/bulan lebih rendah daripada RTM perkotaan Rp151.596/ kapita/bulan. Ratarata pengeluaran RTM nasional Rp128.003/ kapita/bulan. Secara lebih lengkap Tabel 2 menyajikan rata-rata pengeluaran rumah tangga miskin dan tidak miskin di pedesaan dan perkotaan Indonesia.

Jumlah dan persentase rumah tangga penerima raskin di Indonesia dapat dilihat pada Tabel 3. Jumlah rumah tangga penerima raskin secara nasional 23.863 rumah tangga $(45,57$ persen). Rumah tangga penerima raskin di pedesaan sebanyak 17.860 (56,39 persen dari rumah tangga pedesaan). Rumah tangga penerima raskin di perkotaan sebesar $6.003(29,01$ persen dari rumah tangga perkotaan).

\section{Ketepatan Sasaran Raskin}

Dari jumlah rumah tangga miskin pada Tabel 1 dan jumlah rumah tangga penerima raskin pada Tabel 3 dapat diketahui bahwa jumlah rumah tangga penerima raskin lebih banyak daripada jumlah rumah tangga miskin. Hal ini menunjukkan adanya ketidaktepatan sasaran dalam distribusi raskin di Indonesia. Apabila distribusi raskin tepat sasaran maka jumlah rumah tangga penerima raskin seharusnya sesuai dengan jumlah rumah tangga miskin yaitu 18,22 persen di pedesaan, 10,14 persen di perkotaan dan 15,03 persen secara keseluruhan. Namun demikian realitas di lapangan menunjukkan bahwa jumlah rumah tangga penerima raskin lebih besar dibandingkan dengan rumah tangga miskin yaitu 56,39 persen di pedesaan, 29,01 persen di perkotaan dan 45,57 persen di Indonesia. Secara grafis indikasi adanya ketidaktepatan sasaran raskin di Indonesia dapat dilihat pada Gambar 1.

Untuk mengetahui lebih lanjut tingkat ketepatan sasaran distribusi raskin di pedesaan

Tabel 2. Rata-rata Pengeluaran Rumah Tangga Miskin dan Tidak Miskin di Indonesia Tahun 2007 (Rp/kapita/bulan)

\begin{tabular}{|c|c|c|c|}
\hline Lokasi & RTM & Non RTM & Rata-rata \\
\hline Desa & $\begin{array}{c}119.420 \\
(-266,92)\end{array}$ & $\begin{array}{l}309.945 \\
(125,14)\end{array}$ & $\begin{array}{c}275.239 \\
(94,86)\end{array}$ \\
\hline Kota & $\begin{array}{l}151.596 \\
(-63,91)\end{array}$ & $\begin{array}{l}536.720 \\
(118,15)\end{array}$ & $\begin{array}{l}497.659 \\
(107,67)\end{array}$ \\
\hline Indonesia & $\begin{array}{c}128.003 \\
(-206,60)\end{array}$ & $\begin{array}{l}404.710 \\
(155,27)\end{array}$ & $\begin{array}{l}363.132 \\
(133,04)\end{array}$ \\
\hline
\end{tabular}

Sumber: Analisis Data Susenas (2007)

Keterangan:RTM adalah rumah tangga miskin, Non RTM adalah rumah tangga tidak miskin

( ) adalah nilai t-hitung perbedaan rata-rata pengeluaran rumah tangga dengan garis kemiskinan BPS (2007), signifikan pada a $1 \%$ 
Tabel 3. Jumlah dan Persentase Rumah Tangga Penerima Raskin di Indonesia Tahun 2007

\begin{tabular}{lrccccc}
\hline \multirow{2}{*}{ Lokasi } & \multicolumn{2}{c}{ RTR } & \multicolumn{2}{c}{ Non RTR } & \multicolumn{2}{c}{ Jumlah } \\
\cline { 2 - 7 } & \multicolumn{1}{c}{ RT } & \% & RT & \% & Jumlah & \% \\
\hline Desa & 17.860 & $56,39 \%$ & 13.815 & $43,61 \%$ & 31.675 & $100,00 \%$ \\
Kota & 6.003 & $29,01 \%$ & 14.692 & $70,99 \%$ & 20.695 & $100,00 \%$ \\
Indonesia & 23.863 & $45,57 \%$ & 28.507 & $54,43 \%$ & 52.370 & $100,00 \%$ \\
\hline
\end{tabular}

Sumber: Analisis Data Susenas (2007)

Keterangan: RTadalah rumah tangga, RTR adalah rumah tangga penerima raskin, Non RTR: rumah tangga bukan penerima raskin

dan perkotaan Indonesia maka dilakukan analisis tabulasi silang antara rumah tangga miskin dengan rumah tangga penerima raskin seperti terlihat pada Tabel 4 .

Dari Tabel 4 dapat diketahui bahwa ada dua tipe kesalahan yang menyebabkan distribusi raskin tidak tepat sasaran yaitu (1) tidak memberikan raskin kepada rumah tangga miskin dan (2) membagikan raskin kepada rumah tangga tidak miskin. Kedua tipe kesalahan ini terjadi dalam distribusi raskin di Indonesia. Tipe kesalahan pertama ditunjukkan lebih lanjut pada Gambar 2, sedangkan tipe kesalahan kedua ditunjukkan pada Gambar 3.

Pada Gambar 2 terlihat bahwa masih cukup banyak rumah tangga miskin yang tidak menerima raskin yaitu 25,15 persen di pedesaan, 28,44 persen di perkotaan dan 26,03 persen secara keseluruhan. Tipe kesalahan pertama terjadi karena pagu pengalokasian raskin lebih rendah dibandingkan dengan jumlah rumah tangga raskin, alasan non-ekonomi serta alasan lain yang bersifat subyektif. SMERU (2008) melaporkan bahwa pagu raskin pada tahun 2007 hanya untuk 15,8 juta rumah tangga miskin, sedangkan jumlah rumah tangga miskin sebesar 19,1 juta sehingga rumah tangga miskin yang terdaftar sebagai penerima raskin hanya 83 persen dan 17 persen rumah tangga miskin yang lain tidak akan mendapatkan raskin karena memang tidak terdaftar sebagai penerima raskin. Namun demikian, penelitian ini menemukan bahwa masih banyaknya rumah tangga miskin yang tidak menerima raskin tidak hanya disebabkan oleh pagu raskin yang lebih rendah daripada jumlah rumah tangga miskin, tetapi juga disebabkan oleh alasan lain. Hal ini ditunjukkan oleh persentase rumah tangga miskin yang tidak menerima raskin baik di pedesaan, perkotaan dan secara keseluruhan Indonesia lebih besar dari 17 persen yaitu 25,15 persen di pedesaan, 28,44 persen di perkotaan dan 26,03

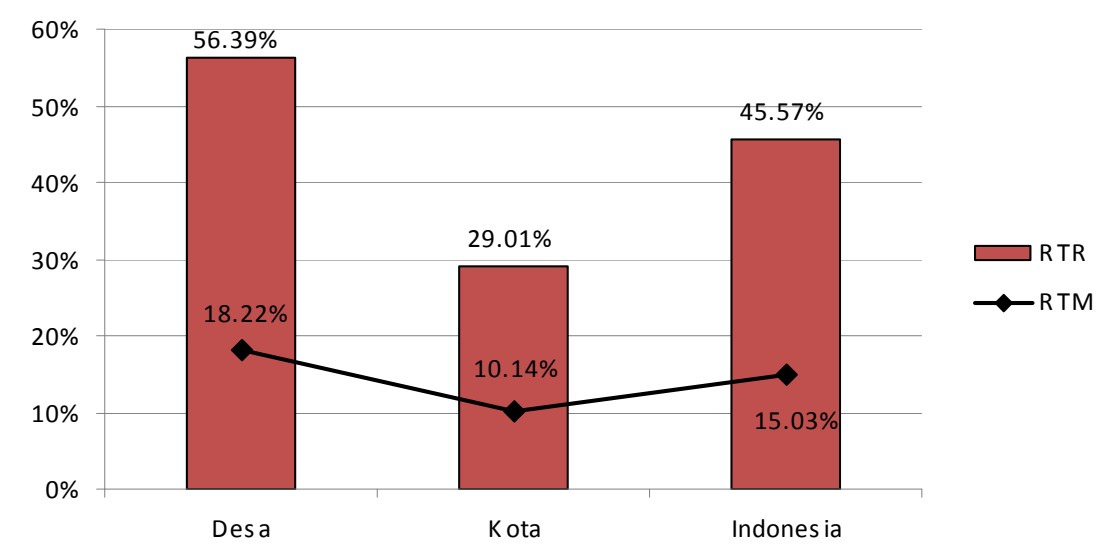

Keterangan: RTR ada rumah tangga penerima raskin, RTM adalah rumah tangga miskin

Gambar 1. Persentase Rumah Tangga Miskin dan Rumah Tangga Penerima Raskin di Indonesia 


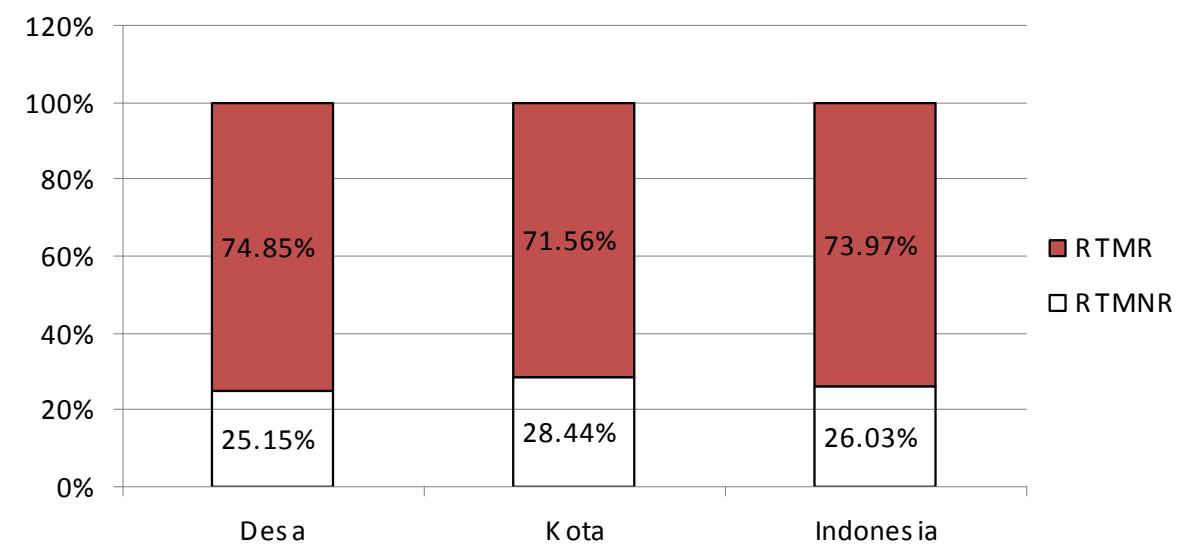

Keterangan: RTMR adalah rumah tangga miskin penerima raskin, RTMNR adalah rumah tangga miskin bukan penerima raskin

\section{Gambar 2. Persentase Rumah Tangga Miskin yang Menerima dan Tidak Menerima Raskin di Indonesia Tahun 2007}

persen di Indonesia. Artinya meskipun pagu alokasi raskin ditingkatkan sama dengan jumlah rumah tangga miskin, akan tetap ada rumah tangga miskin yang tidak menerima raskin yaitu 8,15 persen di pedesaan, 11,44 persen di perkotaan dan 9,03 persen secara nasional. Angka tersebut akan meningkat lagi apabila distribusi tambahan alokasi raskin tidak 100 persen tepat sasaran. Oleh karena itu peningkatan pagu alokasi raskin dan usaha untuk mengurangi pertimbangan-pertimbangan lain dalam distribusi raskin keduanya perlu dilakukan untuk meningkatkan ketepatan sasaran raskin.

Gambar 3 menunjukkan besarnya tipe kesalahan kedua dalam distribusi raskin yaitu membagikan raskin kepada rumah tangga tidak miskin. Rumah tangga tidak miskin yang menerima raskin sebesar 52,27 persen di pedesaan, 24,20 persen di perkotaan dan rata-rata secara nasional 40,54 persen. Tipe kesalahan kedua ini lebih besar dibandingkan dengan tipe kesalahan pertama. Bahkan jika dilihat dari komposisi rumah tangga penerima raskin pada Gambar 4, persentase rumah tangga tidak miskin lebih banyak daripada rumah tangga miskin.

Sebagian besar rumah tangga penerima raskin justru merupakan rumah tangga tidak miskin yaitu sebesar 75,82 persen di pedesaan, 74,98 persen di perkotaan dan 75,61 persen di Indonesia. Rumah tangga miskin yang menerima raskin di pedesaan, perkotaan dan Indonesia masing-masing hanya 24,18 persen, 25,02 persen dan 24,39 persen dari seluruh rumah tangga penerima raskin.

Tipe kesalahan kedua dapat terjadi karena hubungan keluarga, saudara, kerabat, teman sehingga dikenal istilah "bagilur" (raskin dibagikan kepada rumah tangga yang masih terma-

Tabel 4. Jumlah Rumah Tangga Miskin dan Rumah Tangga Penerima Raskin Tahun 2007

\begin{tabular}{lccccccc}
\hline \multirow{2}{*}{ Lokasi } & \multicolumn{3}{c}{ RTM } & \multicolumn{3}{c}{ Non RTM } & \multirow{2}{*}{ Jumlah } \\
\cline { 2 - 6 } & RTR & Non RTR & Jumlah & \multicolumn{1}{c}{ RTR } & Non RTR & Jumlah & \\
\hline Desa & 4,319 & 1,451 & 5,770 & 13,541 & 12,364 & 25,905 & 31,675 \\
Kota & 1,502 & 597 & 2,099 & 4,501 & 14,095 & 18,596 & 20,695 \\
Indonesia & 5,821 & 2,048 & 7,869 & 18,042 & 26,459 & 44,501 & 52,370 \\
\hline
\end{tabular}

Sumber: Analisis Data Susenas (2007)

Keterangan: RTM adalah rumah tangga miskin, Non RTM adalah rumah tangga tidak miskin, RTR adalah rumah tangga penerima raskin. Non RTR adalah rumah tangga bukan penerima raskin 


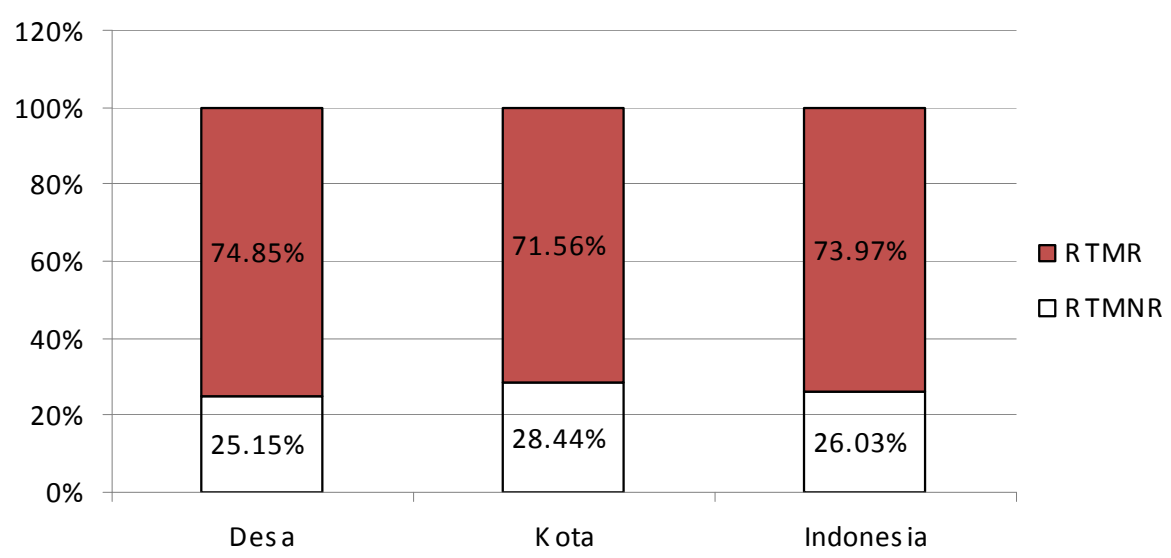

Keterangan: Non RTM-R adalah rumah tangga tidak miskin penerima raskin, Non RTM-NR adalah rumah tangga tidak miskin bukan penerima raskin

\section{Gambar 3. Persentase Rumah Tangga Tidak Miskin yang Menerima dan Tidak Menerima Raskin di Indonesia Tahun 2007}

suk famili). Di samping itu tipe kesalahan kedua juga dapat terjadi karena kekhawatiran pelaksana raskin di tingkat bawah terhadap tidak berjalannya kegiatan-kegiatan sosial di masyarakat seandainya raskin hanya diberikan kepada rumah tangga miskin misalnya rumah tangga yang tidak menerima raskin tidak mau gotong royong, tidak mau siskamling dan lainlain sehingga menyebabkan raskin dibagi rata atau dikenal dengan "bagito".

Kedua tipe kesalahan dalam distribusi raskin di Indonesia bukan disebabkan oleh sulitnya membedakan tingkat kemiskinan antarke- lompok rumah tangga. Hasil uji beda nyata antara rata-rata pengeluaran per kapita per bulan masing-masing kelompok rumah tangga dengan garis kemiskinan BPS (2007) pada Tabel 5 menunjukkan bahwa rata-rata pengeluaran per kapita per bulan rumah tangga miskin baik yang menerima maupun tidak menerima raskin secara signifikan berada di bawah garis kemiskinan, sedangkan rata-rata pengeluaran per kapita per bulan rumah tangga tidak miskin baik yang menerima maupun tidak menerima raskin secara signifikan berada di atas garis kemiskinan. Rata-rata pengeluaran rumah tangga miskin

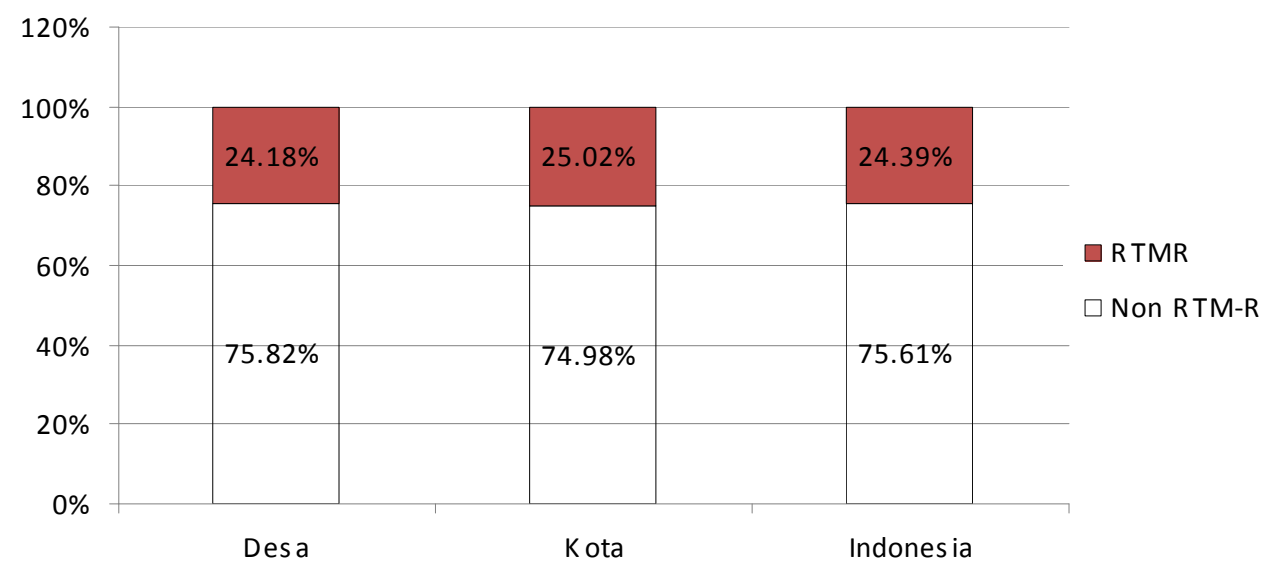

Keterangan: RTMR adalah rumah tangga miskin penerima raskin, Non RTM-R: rumah tangga tidak miskin penerima raskin

Gambar 4. Persentase Rumah Tangga Penerima Raskin di Indonesia Tahun 2007 
Tabel 5. Uji Beda Nyata Rata-Rata Pengeluaran Kelompok Rumah Tangga dengan Garis Kemiskinan BPS (2007) (Rp/Kapita/Bulan)

\begin{tabular}{lccccccc}
\hline \multirow{2}{*}{ Lokasi } & \multicolumn{9}{c}{ RTM } & \multicolumn{3}{c}{ Non RTM } & \multirow{2}{*}{ Rata-rata } \\
\cline { 2 - 6 } & RTR & Non RTR & Rata-rata & RTR & Non RTR & Rata-rata \\
\hline Desa & 119.207 & 120.054 & 119.420 & 261.419 & 363.091 & 309.945 & 275.239 \\
& $(-231,66)$ & $(-132,64)$ & $(-266,92)$ & $(99,04)$ & $(92,93)$ & $(125,14)$ & $(94,86)$ \\
Kota & 149.686 & 156.402 & 151.596 & 326.928 & 603.714 & 536.720 & 497.659 \\
& $(-55,50)$ & $(-32,57)$ & $(-63,91)$ & $(84,72)$ & $(110,23)$ & $(118,15)$ & $(107,67)$ \\
Indonesia & 127.071 & 130.649 & 128.003 & 277.762 & 491.273 & 404.710 & 363.132 \\
& $(-183,00)$ & $(-97,63)$ & $(-206,60)$ & $(126,01)$ & $(134,05)$ & $(155,27)$ & $(133,04)$ \\
\hline
\end{tabular}

Sumber: Analisis Data Susenas (2007)

Keterangan: RTM adalah rumah tangga miskin, Non RTM adalah rumah tangga tidak miskin, RTR adalah rumah tangga penerima raskin, dan Non RTR adalah rumah tangga bukan penerima raskin. ( ) adalah nilai t-hitung perbedaan rata-rata pengeluaran rumah tangga dengan garis kemiskinan BPS (2007), signifikan pada a $1 \%$

yang tidak menerima raskin Rp120.054/kapita/ bulan di pedesaan secara signifikan lebih kecil dari garis kemiskinan BPS (2007) sebesar Rp146.837/kapita/bulan, sedangkan rata-rata pengeluaran rumah tangga miskin perkotaan yang tidak menerima raskin Rp156.042/kapita/ bulan secara signifikan lebih kecil dari garis kemiskinan BPS (2007) sebesar Rp187.942/kapita/bulan. Sebaliknya rata-rata pengeluaran rumah tangga tidak miskin yang menerima raskin baik di pedesaan maupun perkotaan secara signifikan lebih besar dari garis kemiskinan BPS (2007) masing-masing Rp261.419/ kapita/bulan dan Rp326.928/kapita / bulan.

Oleh karena itu untuk meningkatkan ketepatan sasaran raskin diperlukan aturan-aturan yang lebih jelas dan tegas untuk meminimalkan alasan-alasan non ekonomi dalam menentukan rumah tangga penerima raskin. Di samping itu perlu kajian lebih lanjut terhadap kekhawatiran-kekhawatiran yang selama ini berkembang di masyarakat misalnya apakah benar kalau raskin tidak dibagi rata maka kegiatan-kegiatan sosial masyarakat tidak dapat berjalan. Berdasarkan dua tipe kesalahan dalam distribusi raskin di atas dapat ditentukan indeks ketepatan sasaran raskin pada Tabel 6 .

Dari Tabel 6 dapat diketahui bahwa dengan menggunakan garis kemiskinan BPS (2007) maka distribusi raskin di Indonesia baik di pedesaan maupun perkotaan tidak tepat sasaran. IKS bahkan bernilai negatif yaitu -135 persen di pedesaan, -114 persen di perkotaan dan -129 persen secara nasional. IKS yang bernilai negatif menunjukkan masih banyaknya rumah tangga miskin yang tidak mendapatkan raskin (kesalahan tipe pertama sebesar 25 persen di pedesaan, 28 persen di perkotaan dan 26 persen secara nasional) dan banyaknya rumah tangga tidak miskin yang mendapatkan raskin (kesalahan tipe kedua 235 persen di pedesaan, 214 persen di perkotaan dan 229 persen secara nasional). Kesalahan tipe kedua lebih besar dibandingkan dengan tipe pertama. Secara rela-

Tabel 6. Indeks Ketepatan Sasaran Raskin Menurut Kriteria BPS (2007), World Bank dan Asian Development Bank

\begin{tabular}{lccccccccc}
\hline \multirow{2}{*}{ Lokasi } & \multicolumn{3}{c}{ BPS } & \multicolumn{3}{c}{ World Bank } & \multicolumn{3}{c}{ ADB } \\
\cline { 2 - 10 } & e1 & e2 & IKS & e1 & e2 & IKS & e1 & e2 & IKS \\
\hline Desa & $25 \%$ & $235 \%$ & $-160 \%$ & $33 \%$ & $20 \%$ & $47 \%$ & $36 \%$ & $9 \%$ & $55 \%$ \\
Kota & $28 \%$ & $214 \%$ & $-143 \%$ & $42 \%$ & $40 \%$ & $18 \%$ & $49 \%$ & $16 \%$ & $36 \%$ \\
Indonesia & $26 \%$ & $229 \%$ & $-155 \%$ & $35 \%$ & $25 \%$ & $40 \%$ & $40 \%$ & $11 \%$ & $50 \%$ \\
\hline
\end{tabular}

Sumber: Analisis Data Susenas (2007)

Keterangan: e1 adalah kesalahan tipe 1, e2 adalah kesalahan tipe 2, IKS adalah indeks ketepatan sasaran 
Tabel 7. Indeks Ketepatan Jumlah Raskin Tahun 2007

\begin{tabular}{|c|c|c|c|c|}
\hline Lokasi & RTM & Non RTM & Rata-rata & IKJ \\
\hline Desa (kg/bulan) & $\begin{array}{r}11,84 \\
(-54,39)\end{array}$ & $\begin{array}{r}11,53 \\
(-96,11)\end{array}$ & $\begin{array}{r}11,61 \\
(-147,03)\end{array}$ & $58 \%$ \\
\hline Kota $(\mathrm{kg} /$ bulan $)$ & $\begin{array}{r}10,23 \\
(-40,70)\end{array}$ & $\begin{array}{r}10,67 \\
(-59,07)\end{array}$ & $\begin{array}{r}10,56 \\
(-131,98)\end{array}$ & $53 \%$ \\
\hline Indonesia (kg/bulan) & $\begin{array}{r}11,43 \\
(-67,15) \\
\end{array}$ & $\begin{array}{r}11,32 \\
(-112,73) \\
\end{array}$ & $\begin{array}{r}11,35 \\
(-194,17) \\
\end{array}$ & $57 \%$ \\
\hline
\end{tabular}

Sumber: Analisis Data Susenas (2007)

Keterangan: RTM adalah rumah tangga miskin, Non RTM adalah rumah tangga tidak miskin, IKJ adalah indeks ketepatan jumlah ( ) adalah nilai t-hitung perbedaan rata-rata jumlah raskin yang diterima rumah tangga dengan pagu raskin, signifikan pada a $1 \%$

tif distribusi raskin di perkotaan lebih tepat sasaran daripada pedesaan.

Dari Tabel 6 juga dapat diketahui bahwa apabila garis kemiskinan menurut World Bank (WB) sebesar 1 US \$/kapita/hari dan Asian Development Bank (ADB) sebesar 1,25US\$/ kapita/hari digunakan sebagai dasar evaluasi maka distribusi raskin di Indonesia juga belum tepat sasaran, namun lebih tepat sasaran dengan indeks ketepatan sasaran secara nasional masing-masing 40 persen dan 50 persen. Penggunaan garis kemiskinan menurut World Bank dan ADB meningkatkan ketepatan sasaran raskin melalui penurunan tipe kesalahan kedua. Penggunaan garis kemiskinan World Bank dan ADB meningkatkan kesalahan tipe pertama, namun jumlahnya kecil sehingga apabila bobot kesalahan pertama dan kedua sama dalam menentukan ketepatan sasaran maka secara keseluruhan meningkatkan IKS.

\section{Ketepatan Jumlah Raskin}

Dari Tabel 7 dapat diketahui bahwa jumlah ras- kin yang diterima oleh rumah tangga penerima raskin belum tepat jumlah. Rata-rata raskin yang diterima oleh rumah tangga sebesar 11,61 $\mathrm{kg} /$ bulan di pedesaan, $10,56 \mathrm{~kg} /$ bulan di perkotaan dan $11,35 \mathrm{~kg} /$ bulan secara nasional. Jumlah raskin yang diterima oleh rumah tangga tersebut secara signifikan lebih rendah dibandingkan dengan jumlah raskin normatif sebesar $20 \mathrm{~kg} /$ bulan. Distribusi raskin di pedesaan relatif lebih tepat jumlah daripada perkotaan, masing-masing dengan indeks ketepatan jumlah 58 persen dan 53 persen. Indeks ketepatan jumlah raskin secara nasional sebesar 57 persen.

\section{Indeks Ketepatan Harga Raskin}

Dari Tabel 8 dapat diketahui bahwa distribusi raskin di Indonesia belum tepat harga. Ratarata harga raskin di pedesaan sebesar Rp1.315/ $\mathrm{kg}$, sedangkan di perkotaan Rp1.366/kg. Ratarata harga raskin di pedesaan dan perkotaan tersebut secara signifikan lebih mahal dibandingkan dengan harga raskin normatif sebesar Rp1.000/kg. Tabel 8 juga menunjukkan bahwa

Tabel 8. Indeks Ketepatan Harga Raskin Tahun 2007

\begin{tabular}{lcccc}
\hline \multicolumn{1}{c}{ Lokasi } & RTM & Non RTM & Rata-rata & IKH \\
\hline Desa $(\mathrm{Rp} / \mathrm{kg})$ & 1.278 & 1.327 & 1.315 & $68 \%$ \\
& $(46,17)$ & $(86,03)$ & $(129,83)$ & \\
Kota $(\mathrm{Rp} / \mathrm{kg})$ & 1.268 & 1.399 & 1.366 & $63 \%$ \\
& $(24,38)$ & $(42,95)$ & $(90,39)$ & \\
Indonesia $(\mathrm{Rp} / \mathrm{kg})$ & 1.275 & 1.345 & 1.328 & $67 \%$ \\
& $(52,05)$ & $(93,68)$ & $(158,03)$ & \\
\hline
\end{tabular}

Sumber: Analisis Data Susenas (2007)

Keterangan: RTM adalah rumah tangga miskin, Non RTM adalah rumah tangga tidak miskin, IKH adalah indeks ketepatan harga. ( ) adalah nilai t-hitung perbedaan rata-rata harga raskin yang dibayarkan rumah tangga dengan harga raskin program, signifikan pada o $1 \%$ 
distribusi raskin di pedesaan lebih tepat harga daripada perkotaan dengan indeks ketepatan harga berturut-turut 68 persen dan 63 persen.

\section{Faktor-faktor yang Mempengaruhi Rumah Tangga Menerima Raskin}

Hasil analisis ketepatan sasaran raskin di atas menunjukkan bahwa distribusi raskin masih banyak kelemahan antara lain belum tepat sasaran, belum tepat jumlah dan belum tepat harga. Raskin dibagi rata baik di pedesaan maupun perkotaan. Untuk mengetahui faktorfaktor yang mempengaruhi suatu rumah tangga menerima raskin atau tidak, pada Tabel 9 disajikan hasil analisis regresi model logistik penerimaan raskin di Indonesia.

Secara bersama-sama pendidikan, jenis kelamin, umur, jumlah anggota rumah tangga, pendapatan, pekerjaan, lanta rumah dan lokasi mempengaruhi probabilitas suatu rumah tangga menerima raskin atau tidak dengan koefisien determinasi sebesar 19,84 persen. Sedangkan variabel penjelas yang secara individual berpengaruh nyata terhadap probabilitas rumah tangga menerima raskin adalah pendidikan, jumlah anggota rumah tangga, pendapatan, pekerjaan, lantai rumah dan lokasi.

Pendidikan kepala rumah tangga berpengaruh negatif dan sangat nyata terhadap probabilitas penerimaan raskin. Semakin tinggi tingkat pendidikan kepala rumah tangga maka probabilitas menerima raskin semakin berku- rang. Hasil ini sesuai dengan dugaan sebelumnya bahwa pendidikan akan mengurangi peluang suatu rumah tangga menerima raskin. Rumah tangga dengan tingkat pendidikan yang lebih tinggi akan memiliki pengetahuan dan keahlian lebih tinggi, peluang bekerja dan membuka usaha ekonomi lebih besar sehingga tidak termasuk dalam kelompok rumah tangga penerima raskin.

Jenis kelamin kepala rumah tangga tidak mempengaruhi probabilitas suatu rumah tangga menerima raskin atau tidak. Kepala rumah tangga laki-laki maupun perempuan memiliki peluang yang sama untuk menerima raskin. Hal ini menunjukkan tidak adanya bias gender dalam distribusi raskin di Indonesia.

Umur kepala rumah tangga juga tidak mempengaruhi probabilitas suatu rumah tangga menerima raskin atau tidak. Kepala rumah tangga tua maupun muda memiliki peluang yang sama untuk menerima raskin. Hal ini juga menunjukkan tidak adanya diksriminasi umur dalam distribusi raskin di Indonesia.

Jumlah anggota rumah tangga berpengaruh negatif dan sangat nyata terhadap probabilitas penerimaan raskin. Semakin banyak jumlah anggota rumah tangga maka probabilitas menerima raskin semakin berkurang. Secara teoritis, pengaruh jumlah anggota rumah tangga terhadap peluang penerimaan raskin bisa positif maupun negatif. Hasil estimasi empiris yang bertanda negatif dalam penelitian ini menunjukkan bahwa sebagian besar anggo-

Tabel 9. Faktor-faktor yang Mempengaruhi Rumah Tangga Menerima Raskin

\begin{tabular}{|c|c|c|c|c|c|}
\hline Variabel & Tanda harapan & Koefisien & & z-Statistic & Prob. \\
\hline Konstanta & $+/-$ & 3,579508 & $* * *$ & 12,516320 & 0,0000 \\
\hline Pendidikan & - & $-0,299759$ & $* * *$ & $-30,497040$ & 0,0000 \\
\hline Jenis kelamin & $+/-$ & $-0,099267$ & & $-0,356486$ & 0,7215 \\
\hline Umur & + & $-0,000466$ & & $-0,534611$ & 0,5929 \\
\hline Anggota RT & + & $-0,118885$ & $* * *$ & $-17,758390$ & 0,0000 \\
\hline Pendapatan & - & $-4,79 \mathrm{E}-06$ & $* * *$ & $-57,657270$ & 0,0000 \\
\hline Pekerjaan & - & $-0,231671$ & $* * *$ & $-9,553659$ & 0,0000 \\
\hline Lantai rumah & - & $-0,742964$ & $* * *$ & $-21,300280$ & 0,0000 \\
\hline Lokasi & - & $-0,412567$ & $* * *$ & $-16,734110$ & 0,0000 \\
\hline LR statistic (8 df) & & 13338,75 & \multirow{2}{*}{\multicolumn{2}{|c|}{ McFadden R-squared }} & 0,198398 \\
\hline Probability(LR stat) & & 0,000000 & & & \\
\hline
\end{tabular}


ta rumah tangga produktif dan tidak menambah beban rumah tangga, sebaliknya justru mengurangi beban rumah tangga sehingga tidak termasuk dalam kelompok rumah tangga penerima raskin.

Pendapatan berpengaruh negatif dan sangat nyata terhadap probabilitas penerimaan raskin. Semakin tinggi pendapatan rumah tangga maka probabilitas menerima raskin semakin berkurang. Hasil ini sesuai dengan dugaan sebelumnya bahwa raskin akan didistribusikan kepada rumah tangga dengan pendapatan rendah. Rumah tangga dengan pendapatan lebih tinggi tidak termasuk kelompok rumah tangga penerima raskin.

Pekerjaan utama kepala rumah tangga juga berpengaruh negatif dan sangat nyata terhadap probabilitas penerimaan raskin. Pekerjaan di bidang pertanian memiliki probabilitas lebih kecil untuk menerima raskin. Probabilitas raskin diberikan kepada rumah tangga non pertanian lebih besar.

Lantai rumah berpengaruh negatif dan sangat nyata terhadap probabilitas penerimaan raskin. Rumah tangga yang bangunan rumahnya masih berlantai tanah memiliki peluang lebih besar untuk menerima raskin dibandingkan dengan rumah tangga yang bangunan rumahnya sudah berlantai bukan tanah misalnya sudah di semen atau keramik.

Keragaman dalam distribusi raskin juga dijelaskan oleh lokasi. Rumah tangga pedesaan memiliki peluang yang lebih besar untuk menerima raskin dibandingkan dengan rumah tangga perkotaan.

\section{SIMPULAN}

Berdasarkan garis kemiskinan BPS (2007) distribusi raskin di Indonesia belum tepat sasaran dengan indeks ketepatan sasaran - 135 persen di pedesaan, -114 persen di perkotaan dan -129 persen secara nasional. Indeks ketepatan sasaran yang bernilai negatif menunjukkan masih banyaknya rumah tangga miskin yang belum mendapatkan raskin yaitu 25,15 persen di pedesaan, 28,44 persen di perkotaan dan 26,03 persen secara nasional; serta banyaknya rumah tangga tidak miskin yang mendapatkan raskin yaitu 52,27 persen di pedesaan, 24,20 persen di perkotaan dan 40,54 persen secara nasional.

Berdasarkan garis kemiskinan World Bank dan ADB, distribusi raskin di Indonesia juga belum efektif, namun indeks ketepatan sasaran bernilai positif. Indeks ketepatan sasaran menurut garis kemiskinan World Bank adalah 67 persen di pedesaan, 58 persen di perkotaan dan 65 persen secara nasional. Indeks ketepatan sasaran menurut garis kemiskinan ADB adalah 64 persen di pedesaan, 52 persen di perkotaan dan 60 persen secara nasional.

Tingginya ketidaktepatan sasaran raskin menurut kriteria BPS disebabkan oleh garis kemiskinan BPS yang terlalu rendah, alokasi anggaran raskin lebih rendah daripada jumlah rumah tangga miskin, dan penyimpangan yang dilakukan oleh masyarakat.

Distribusi raskin di Indonesia belum tepat jumlah dengan indeks ketepatan jumlah 58 persen di pedesaan, 53 persen di perkotaan dan 57 persen secara nasional. Rata-rata raskin yang diterima oleh rumah tangga sebesar $11,61 \mathrm{~kg} /$ bulan di pedesaan, $10,56 \mathrm{~kg} /$ bulan di perkotaan dan 11,35 kg/bulan secara nasional. Jumlah raskin yang diterima oleh rumah tangga tersebut secara signifikan lebih rendah dibandingkan dengan jumlah raskin normatif sebesar 20 $\mathrm{kg} /$ bulan.

Distribusi raskin di Indonesia belum tepat harga dengan indeks ketepatan harga 68 persen di pedesaan, 63 persen di perkotaan dan 67 persen secara nasional. Rata-rata harga raskin di pedesaan sebesar Rp1.315/kg, sedangkan di perkotaan Rp1.366/kg. Rata-rata harga raskin di pedesaan dan perkotaan tersebut secara signifikan lebih mahal dibandingkan dengan harga raskin normatif sebesar Rp1.000/kg

Probabilitas suatu rumah tangga menerima raskin atau tidak sebagian dapat dijelaskan oleh pendidikan, jenis kelamin, umur, jumlah anggota rumah tangga, pendapatan, pekerjaan, lanta rumah dan lokasi

Saran. Penggunaan garis kemiskinan BPS untuk menentukan target dalam distribusi raskin dan kebijakan publik lainnya perlu ditinjau kembali karena terlalu rendah dan kurang realistis sehingga terkesan Program Raskin sangat tidak tepat sasaran. Dalam kondisi anggar- 
an raskin yang lebih longgar, garis kemiskinan World Bank dan ADB dapat digunakan sebagai pengganti garis kemiskinan BPS karena lebih mendekati kondisi nyata di masyarakat.

Dalam kondisi anggaran yang terbatas pemerintah perlu memprioritaskan usaha perbaikan pelaksanaan Program Raskin melalui pengurangan kesalahan tipe pertama dan kedua secara paralel dengan membuat dan melaksanakan aturan yang jelas dan tegas, serta menerapkan sistem reward and punishment,

Perlu kajian yang lebih mendalam terhadap banyaknya rumah tangga tidak miskin yang menerima raskin, apakah hal ini merupakan fenomena masyarakat ataukah kesalahan yang dilakukan oleh petugas. Apabila banyak rumah tangga tidak miskin yang aktif minta raskin maka tugas pemerintah untuk menghapus budaya ini. Apabila rumah tangga tidak miskin menerima raskin secara pasif (karena diberi oleh petugas) maka pemerintah perlu menerapkan sistem reward and punishment yang jelas dan tegas serta menerapkan model-model distribusi raskin yang lain

\section{DAFTAR PUSTAKA}

Adinugroho, L.W. 2010). Efektifitas dan Efisiensi Distribusi Raskin Perum Bulog Divre Kalimantan Timur di Kota Balikpapan. Tesis PS S2 MMA UGM (tidak dipublikasikan).

BPS. 2007. Tingkat Kemiskinan di Indonesia Tahun 2007. Berita Resmi Statistik No.38/ 07/Th.X, 2 Juli 2007. Jakarta: Badan Pusat Statistik.

BULOG. 2010a. Sekilas RASKIN (Beras untuk Rakyat Miskin). http://www.bulog.go.id Diakses tanggal 14 Juli 2010.

BULOG. 2010b. Studi Evaluasi Raskin: Kritik dan Pujian Sejak Awal Diluncurkan Sampai Sekarang (1998-2004). http://www. bulog.go. id/. Diakses tanggal 14 Juli 2010.

Departemen Dalam Negeri dan Perum Bulog. 2007. Pedoman Umum Program untuk Ke- luarga Miskin (RASKIN) Tahun 2007. Jakarta: Depdagri dan Bulog.

Departemen Dalam Negeri dan Perum Bulog. 2008. Pedoman Umum Program Untuk Keluarga Miskin (RASKIN) Tahun 2008. Jakarta: Depdagri dan Bulog.

Dunn, W.N. 2000. Pengantar Analisis Kebijakan Publik. Terjemahan oleh Samodra Wibawa dkk. Edisi Kedua. Cetakan Ketiga. Yogyakarta: Gadjah Mada University Press.

Gruber, Jonathan. 2005. Public Finance and Public Policy. New York: Worth Publisher.

Hastuti dkk. 2008. Efektivitas Program Raskin. Jakarta: SMERU Research Institute.

Hutagaol, M.P. dan Alla Asmara. 2008. Analisis Efektivitas Kebijakan Publik Memihak Masyarakat Miskin; Studi Kasus Pelaksanaan Program Raskin di Provinsi Jawa Barat pada Tahun 2007. Jurnal Agro Ekonomi, Vol. 26 No. 2, Oktober 2008: 145165.

Prasmatiwi, Nordiana. 2010. Efektivitas dan Efisiensi Distribusi Raskin di Kabupaten Sleman. Skripsi S1 Jurusan Sosial Ekonomi Pertanian Fakultas Pertanian UGM (tidak dipublikasikan). Yogyakarta: UGM.

Purwanti, Dian. 2010. Analisis Permintaan Beras pada Rumah Tangga Penerima Raskin di Kecamatan Salam Kabupaten Magelang. Skripsi S1 Jurusan Sosial Ekonomi Pertanian Fakultas Pertanian UGM (tidak dipublikasikan). Yogyakarta: UGM.

Siddik, Akhmad. 2009. Analisis Ketepatan Sasaran Raskin di Kecamatan Depok, Sleman. Skripsi S1 Fakultas Pertanian UGM. Tidak Dipublikasikan. Yogyakarta: UGM.

Stiglitz, J.E. 2000. Economics of the Public Sector. New York: W.W. Northon and Company.

Tabor, S.R. and M.H. Sawit. 2001. Social Protection via Rice: the OPK Program. The Developing Economies, Vol. XXXIX, No. 3: 267-294. 